\title{
INVESTIGATION TOWARDS THE LONG-RUN PERFORMANCE OF INITIAL PUBLIC OFFERINGS: EVIDENCE FROM INDONESIAN CAPITAL MARKET
}

\author{
Lioniva Emasari $^{1}$ \\ BINUS UNIVERSITY INTERNATIONAL, Jakarta \\ Dewi Tamara ${ }^{2}$ \\ BINUS BUSINESS SCHOOL, Jakarta
}

\begin{abstract}
We study the long-term performance of IPO share issued in Indonesia during the 1996-2001 periods. The IPOs in this period are mostly concentrated in Finance, Trade, Property and Basic Industry \& Chemicals. The cumulative abnormal return (CAR) and buy-and-hold abnormal return (BHAR) in the third year are $15.83 \%$ and negative $68.02 \%$, respectively. The CAR and BHAR in the fifth year are negative $1 \%$ and negative $139.7 \%$, respectively. The highest CAR for 3 and 5 years are mining industry, with $289.29 \%$ and $226.80 \%$, respectively. The lowest CAR for third year is trade, service \& investment industry, with negative $59.36 \%$ and fifth year is agriculture with negative 59.72\%. The lowest BHAR for third and fifth year is trade, service and investment industry with negative $113.01 \%$ and negative 230.99 respectively. The long-run performance using cumulative abnormal return is similar with the market and cannot outperform the market.
\end{abstract}

Keywords: investigation, long-run performance, IPO, capital market.

\section{INTRODUCTION}

An Initial Public Offering (IPO) occurs when a company sells its shares to public investors for the first time. Companies find IPOs as an attractive

${ }^{1,2}$ Lioniva Emasari is an alumni of BINUS UNIVERSITY INTERNATIONAL (lionivalim@yahoo.com). Dewi Tamara is a faculty of BINUS BUSINESS SCHOOL (dtamara@binus.edu). 
way of acquiring additional source of capital to finance further growth and investment. IPOs also act as a venue that enables shareholders to sell their stake of ownership in the company.

A company can go public for various reasons. One major reason is to raise equity by creating a transfer of funds from the capital market to the issuing company. Other reasons include easier access to acquire takeover targets and increases in value of companies. Companies may also choose to go public to increase publicity and public's awareness about the existence of the company.

Since Ritter (1991) documented that IPOs underperform in the long-run, various researchers have tried to do the same research in different countries. These researches of IPOs yield similar conclusions that IPOs underperform in the long-run. IPO firms experience underperformance in stock prices compared to non-IPO companies and the period of underperformance usually lasts for three to five years after the stock offering.

Although there are plenty of researchers regarding IPOs in different countries, there is limited research in Indonesia. A few studies are done by Pujiharjanto (2003), Martani (2004), Suroso (2005), and Suherman (2009). The results achieved from these studies show that Indonesian IPOs underperform the market in the long-run.

Data used is limited to Indonesian companies listed in the Indonesian Stock Exchange in 1996-2001. For long-run performance, the author compares returns of IPO companies with market return from Jakarta Composite Index. The research is design to answer the following questions :

a. To investigate the long-run performance of Indonesian IPO companies in the Indonesian Stock Exchange.

b. To investigate the relationship between age, gross proceeds, and annual sales of IPO companies towards their long-run performance.

c. To analyze whether investing in Indonesian capital market gives profitability to public investors.

This paper will provide deeper understanding to academic researches regarding the long-run performance of IPOs in Indonesia and facilitate knowledge for students or academicians in their studies. 
This paper provides deeper understanding for newly issuing companies regarding IPOs and will help listed companies to understand their performances after the IPO and learn to conduct a good valued offering for the seasoned equity offering.

Public investors need to learn how companies conduct IPOs and their performances. The author hopes that this study will help investors to become more analytical and wiser in placing their investments.

In answering the research questions stated above, this paper will investigate the following six hypotheses:

$H_{1}$ : The cumulative abnormal return (CAR) of initial public offering companies in Indonesia significantly underperforms the market in the long-run.

$\mathrm{H}_{2}$ : The buy-and-hold abnormal return (BHAR) of initial public offering companies in Indonesia significantly underperforms the market in the long-run.

H3: There is a relationship between initial return of IPOs and their long-run performance.

H4: There is a relationship between age of establishment of IPO companies and their long-run performance.

H5: There is a relationship between gross proceeds in IPOs and their long-run performance.

H6: There is a relationship between annual sales of IPO companies and their long-run performance.

For investigating the long-run market performance of Indonesian IPOs, the two measurements used are Cumulative Abnormal Return (CAR) and Buy-and-hold Abnormal Return (BHAR). The data for stock returns is taken from Indonesian Stock Exchange and for the benchmark is taken from the Jakarta Composite Index.

In pursuing the goals of this study, details of theoretical framework appear in Section 2. The data is discussed in section 3, while section 4 will discuss the regression result. The last section will discuss about conclusions. 


\section{THEORITICAL FRAMEWORK}

Ritter (1998) defines IPO as an event when a security is sold to the general public for the first time. Geddes (2003) states IPO as the first sale of a company's shares to the public and the listing of shares on a stock exchange. Another definition of IPO is the transition from being a private company to a public company (Foerster 2001).

A business is initially private at the beginning, but then as it grows significantly large the company becomes optimal to go public. Private companies do IPOs for various reasons. Foerster (2001) elaborate the functions of an IPO as:

"The IPO provides a fresh source of capital that is critical to the growth of the firm and provides the founder and other shareholders such as venture capitalists a liquid market for their shares. From an institutional investor's perspective, the IPO provides an opportunity to share in the rewards of the growth of the firm."

There are three main interested parties in an IPO, which are the issuing company, the shareholders, and the public investors. Besides those three main parties, there also other third-party individuals and organizations that helped those three main parties to achieve their objectives through assisting in completing the procedures or by giving advices for the IPO process.

Issuing companies are already operating companies that decide to sell their stocks to the public. To be able to go public in Indonesia, the company has to meet the requirements set by BAPEPAM and the Indonesian Stock Exchange. After a company has made the decision to go public, the next important step is to choose an investment bank for advices and to perform the underwriting functions related to the offering. The role of underwriters is to help the issuing firm market the IPO stocks, provide all the necessary filings, and actively participate in determining the offer price.

The shareholders that want to sell their stake of ownership in a company will sell their shares in an IPO. Geddes (2003) states the purpose of shareholders selling their shares is to maximize proceeds, maximize value of share price performance, and be seen as part of a successful transaction. Investors are people from public society that bought the shares offered by the issuing companies. There are two types of investors, individual and 
institutional investors. Underwriters generally prefer institutional investors since they can buy shares in large volumes and tend to hold the shares for long-term for being able to handle the risks.

Besides underwriters, there are also other third party intermediaries that support the IPO process. Public accountants are independent auditors that ensure the financial data shown to public investors are reliable. Appraisal companies appraise the issuing company's assets and measure the value of the firm's total fixed assets. Law consultants are needed by issuing companies for their legal opinions regarding matters of the IPO process, in which there are legal requirements that issuing companies must comply with.

In the study done by Brau and Fawcett (2006), they summarized four lists of reasons that motivate private companies to go public: Firstly, companies decide to do IPOs when external equity can minimizes their cost of capital and raises the company's value. Secondly, IPOs act as opportunities for shareholders to cash out. Owners of shares in an issuing company sell their shares in an IPO usually to achieve personal gain where they prefer to trade their shares for cash. Thirdly, besides holding the role for giving capital access, IPOs are also considered as the first step in which a company can be taken over at an attractive price and act as a takeover facilitator. Finally, IPOs are seen as a strategic move. IPOs diversify the ownership stakes in a company.

The first and most cited benefit is the ability of IPOs to provide broader and better access towards capital. Public companies have more sources of capital than private companies because IPOs open up a new pathway to reach the public market.

Liquidity is the second advantage of IPOs. The existence of stock exchanges acts as a medium where companies can sell their shares readily to the public market. By listing shares in stock exchanges, companies can create a market for its shares in which there are participations from buyers and sellers.

The third advantage of IPOs is that it provides companies with indirect monitoring. Pagano et al. (1998) assert that the stock market also acts as a managerial discipline device by constantly creating the awareness of a hostile takeover and by exposing market's assessment regarding managerial decisions. Furthermore, they argue that companies can use the 
information embodied in the share price to ensure that management performs well by indexing their salaries to the share price.

Last and fourth advantage of IPO is the enhanced image of the issuing company. As a company goes public, it increases disclosure regarding company's operations and investments. The increased visibility creates more awareness in the eyes of the public.

The first disadvantage of an IPO is the occurrence of profit sharing between issuing company and shareholders. This is especially seen when the company is in a successful stage, where future success and profits have to be shared with outside investors.

Second disadvantage of IPOs is the increased disclosure of the issuing company to the public causing a loss of confidentiality. Disclosures of the company may include exposing its financial statements, operational activities, future investments, research and developments, as well as business strategy for future projects. Many companies repent going public because it means the company will have to expose information that may endanger its future prospects due to loss of confidentiality to its competitors.

The third disadvantage of conducting IPOs is the considerable costs paid by the issuing company. Geddes (2003) asserts that the commissions taken by investment bankers range between 2 to 7 percent from the total amount raised in the IPO. Besides the initiation costs, the issuing company also has to incur maintenance costs such as stock exchange fees, management time, more extensive audits and reporting, and reconciliation of accounts when listed on a stock exchange.

The Indonesian Stock Exchange has listed some requirements for companies to be listed in the stock exchange, which are ${ }^{2}$ :

1. The company has been operating for at least 12 months.

2. The company must have at least 5 billion rupiah in net tangible assets.

3. The company has received an Authentic Without Exception opinion from a public accountant registered in BAPEPAM-LK for its latest audited annual financial report.

\footnotetext{
${ }^{2}$ IDX, 2009
} 
4. The company has sold at least 50 million shares or $35 \%$ of its total issued shares.

5. The company must have at least 500 shareholders.

In order for a company to conduct a public offering, the company can appoint one or more underwriters to help prepare all the requirements needed to conduct the public offering. The Indonesian Stock Exchange has listed the requirements, which are:

1. The approval of shareholders through the General Meeting of Shareholders.

2. Prepare the needed documents such as

a. Financial report audited by a public accountant registered in BAPEPAM-LK

b. Corporate budgeting along with its amendments prepared by a notary and approved by a competent authority.

c. Legal audit by a legal consultant registered in BAPEPAM-LK

d. Report from an independent appraiser if needed.

e. Several other documents as arranged in prevailing provisions.

Suherman (2009) did a study regarding the long-run performance of Indonesian IPOs. Result from Suherman's study shows difference results in the long-run performance of IPOs. CAR measurement reveals insignificant underperformance 3 years after listing for both the equalweighted CARs, $-10.72 \%$ and $-24.96 \%$, and value-weighted CARS, $6.73 \%$ and $-9.21 \%$. However, the BHAR measurement reveals a significant underperformance 3 years after listing for the equal-weighted BHARs, $-108.46 \%$ and $-114.34 \%$, and a significant outperformance for the value-weighted BHARs, 25.57\% and 23.93\%.

Peng (2008) conducted a study regarding the long-run performance of 166 Chinese IPOs. The analysis indicates that the aftermarket performance of Chinese IPOs shows negative returns in the long-run. The average marketadjusted cumulative return and buy-and-hold return three years after listing are $-32.02 \%$ and $-20.88 \%$, which are significantly negative. Furthermore, Peng (2008) also did a cross-sectional analysis to explain the long-run underperformance of Chinese IPOs. The results show that the aftermarket performance is positive after 6 months from listing but negative the periods after. 
Sohail and Nasr (2007) studied the performance of 50 IPOs listed on the Karachi Stock Exchange (KSE) in 2000 to 2006. Result from the investigation done implies a significantly negative long-run return for the Pakistan IPOs. Sohail and Nasr found that the average underpricing is $35.66 \%$ with average market-adjusted cumulative return and buy-and-hold abnormal return over one year after listing using market adjusted model of $-19.67 \%$ and $-38.10 \%$.

Kooli, L'Her, and Suret (2003) measured 141 Canadians IPOs over the years 1986 and 2000. The result of the analysis concludes that the IPOs show underperformance in the long-run. Value-weighted CARs are positive in years 1 and 2, but negative in year 3 with return of $-5.37 \%$. Similarly, the value-weighted BHARs also show positive returns in years 1 and 2, but negative in year 3 with return of $-8.8 \%$. This asserts that the year to year performance of Canadian IPOs kept on decreasing. The level of underpricing and analyst's long-term growth forecasts are argued to be significant determinants of performance (Kooli et al., 2003).

Chorruk and Worthington (2009) studied 55 IPOs listed on the Thai Market for Alternative Investments (MAI) from the periods September 2001 to October 2008. Results from the analysis indicates that the cumulative benchmark-adjusted return is always positive or above zero until month 36. From the CAR returns, the smallest IPOs have consistently negative CARs for the 36 months period; the medium sized IPOs have consistently positive CARs for the same period, and the larger sized IPOs have negative CARs after 12 months period. As for the BHAR, all IPOs show positive BHARs except for month 24.

Thomadakis, Nounis, and Gounopoulos (2009) examined 254 Greek IPOs in 1994 to 2002. After the investigation, the result shows a trend of underperformance in the long-run. The BHAR and CAR returns reveal a significant over-performance only for 2 years. Negative returns occur in the period that follows, indicating an underperformance.

Chi, McWha, and Young (2008) conducted an investigation towards 101 New Zealand IPOs taken in 1991-2005. To measure the market performance of the IPOs, they calculated the three year CARs and three year BHARs.

Result of the analysis shows that the IPOs underperform the market in the years following the offering. The average three year CAR adjusted against the market is $-42.4 \%$ and the three year CAR adjusted with the small firm 
index for small firms is $-47.8 \%$, both are significant at the $1 \%$ level. The average three year BHARs are also significantly negative at the $1 \%$ level, with the BHAR adjusted against the market as $-27.8 \%$ and BHAR adjusted for small firm index as $-36 \%$.

Chi et al. (2008) states several hypotheses for the long-run underperformance of IPOs. First, they argue that investors generally put high emphasis on short-term prospects when valuing a security, which lead to a high initial return and low long-run return. Second, they expect that start-up firms would have relatively poorer market performance due to their uncertainty regarding future operations. Third, firms that conduct their offerings in a 'hot IPO period' tend to have worse long-run market performance due to the positive market sentiment at the time of the offering, which over-values the firm's securities.

\section{DATA AND RESEARCH METHODOLOGY}

Since Ritter (1991) documented the long-run underperformance of IPOs in the U.S., many researchers have been repeating these investigations in different countries. Kooli et al. (2003), Sohail et al. (2007), Peng (2008), and Chorruk et al. (2009) has investigated the performance of IPOs in Canada, Pakistan, China, and Thailand and their results indicate that IPOs underperform the market and matching firm in the long-run.

The same studies have also been conducted by several researchers in Indonesia. Pujiharjanto (2003) examined one year performance of IPOs in Indonesia and found an underperformance of 9.8\%. Martani (2004) did a research on 297 IPO firms and found underperformances of $35.37 \%$ and $19.93 \%$ five years after the IPO. Suroso (2005) investigated the long-run

performance of 216 IPOs and his result shows the IPOs underperform the market by $18.95 \%$.

In accordance with the findings mentioned above, to further investigate the long-run market performance of Indonesian IPOs to find out whether the same underperformance phenomenon also exists and to answer the first research question "How is the long-run performance of Indonesian IPOs?” two hypotheses are developed: 
H1: The cumulative abnormal return (CAR) of initial public offering companies in Indonesia significantly underperforms the market in the long-run.

$\mathrm{H}_{2}$ : The buy-and-hold abnormal return (BHAR) of initial public offering companies in Indonesia significantly underperforms the market in the long-run.

Previous researchers related to initial public offerings have documented the tendency of IPOs to provide high abnormal first-day returns, also called as IPO underpricing. A well-known view from Miller (1977) stated that fads occur in IPOs and that the poor long-run performance of IPO companies is a result of overvaluation caused by over-optimism. In the long-run, as the true value of the IPO companies increases over time, the long-run returns decrease.

Suherman (2009) investigated the long-run performance of 101 Indonesian IPOs in 1990-2005. His results documented a negative relationship between initial returns and long-run performance of IPOs. This implies that offerings with better first day performances have poorer long-run performance. Thus, in order to answer the second research question "Is there a relationship between initial return and long-run returns of IPO stocks?” the second hypothesis is developed as follows:

H3: There is a relationship between initial return of IPOs and the long-run performance of IPO companies.

Enormous studies regarding IPOs have investigated the relationship between the age of IPO companies from establishment up until they went public with their long-run performances. Ritter (1991) in his well-known research regarding long-run performance of IPOs have documented a strong monotone relation between age and aftermarket performance. Firms with older age when they decide to become public are seen to have better average 3-year holding period total return compared to those with younger age. Accordingly, with the intention to answer the third research question "Is there a relationship between age of companies and their long-run performance?” a third hypothesis has been developed: 
H4: There is a relationship between age of establishment of IPO companies and their long-run performance.

Gross proceed is the amount of earnings received by IPO companies when they decide to issue shares to the public. Ritter (1991) found that companies with larger gross proceeds have better long-run returns. Ritter et al. (2002) also documented the tendency of IPO companies with high gross proceeds to perform poorly in the long-run. Suherman (2009) in Indonesia also documented a positive relationship between gross proceeds and long-run performance of IPOs. Hence, to answer the fourth research question "Is there a relationship between gross proceeds of IPO companies and their long-run performance?" the following hypothesis is developed as:

H5: There is a relationship between gross proceeds in IPOs and long-run performance of IPO companies.

Ritter (1991) did a cross-sectional analysis of IPO companies by industry. The result shows that companies with the highest mean annual sales have the highest three year holding period total return of $128.21 \%$. In order to satisfy the author's curiosity regarding this matter and to answer the fifth research question "Is there a relationship between annual sales of IPO companies and their long-run performance?" a fifth hypothesis has been developed:

H6: There is a relationship between annual sales of IPO companies and their long-run performance.

\section{Research Methodology}

The monthly abnormal returns of Indonesian IPOs are calculated with Cumulative Abnormal Returns (CAR) and Buy-and-Hold Abnormal Returns (BHAR). These monthly returns are calculated based on the date of the IPOs. Furthermore, the monthly abnormal return of IPOs will be matched with the monthly return from Jakarta Composite Index.

Initial returns are calculated as: 


$$
I R_{i}=\frac{P_{i, 1}-P_{i, 0}}{P_{i, 0}}
$$

The monthly returns of stocks are calculated as:

$$
r_{i, t}=\frac{P_{i, t}-P_{i, t-1}}{P_{i, t-1}}
$$

Where $P_{i, 0}$ is the offering price, $P_{i, 1}$ is the first day closing price, $P_{i, t}$ is the closing price of stock $i$ at month $t$ and $P_{i, t-1}$ is the closing price of the selected stock at the previous month.

The monthly stock returns adjusted to the benchmark (market) monthly return is calculated as:

$$
a r_{i, t}=r_{i, t}-r_{m, t}
$$

Where $r_{i, t}$ is the monthly return of stock $i$ at time $t$ and $r_{m, t}$ is the monthly return of the IHSG at the same period.

For calculating CARs, monthly returns for both the IPO companies and the benchmark are measured for 3 years and 5 years period after the IPO. The average-adjusted return of $n$ number of stocks for event year $t$ is calculated as:

$$
A R_{t}=\frac{1}{n} \sum_{i=1}^{n} a r_{i, t}
$$

where $a r_{i, t}$ is monthly stock returns adjusted to the benchmark (market) monthly return.

The CAR from year $s$ to year $t$ is defined as:

$$
C A R_{t}=\sum_{s=1}^{t} A R_{s}
$$

The CAR for the 3 year period is achieved by adding the CAR of year 1 until year 3 , inserting $s=1$ and $t=3$, whereas the CAR for the 5 year period is achieved by adding the CAR from year 1 until year 5 , inserting $s=1$ and $t=5$. A positive (negative) value indicates that the IPOs outperform (underperform) the market in the selected period. 
A simple t-test is used to test the null hypothesis of zero mean marketadjusted CAR:

$$
t=\frac{C A R_{i, t} * \sqrt{n_{t}}}{\sigma\left(C A R_{i, t}\right)}
$$

As for the BHAR (Bessler and Thies 2007), it is calculated as:

$$
B_{H A R_{i, T}}=\left[\left(\prod_{t=1}^{T} 1+r_{i, t}\right)-\left(\prod_{t=1}^{T} 1+r_{m, t}\right)\right]
$$

$B H A R_{i, T}$ is the buy-and-hold abnormal return for stock $i$ in period $T$. Where, $T$ is 36 months for the 3 year period and 60 months for the 5 year period, $r_{i, t}$ is the monthly return of a stock, and $r_{m, t}$ is the monthly return of the market index.

The mean market-adjusted BHAR for a period $t$ is calculated as:

$$
\text { BHAR }_{t}=\frac{1}{n} \sum_{t=1}^{n} B H A R_{i, T}
$$

where $n$ is the number of stocks in the sample.

The BHAR measurement is used to identify the return gained by investors from a buy and hold strategy, where the stock is purchased at the first closing market price and is held until 3 and 5 years. A positive (negative) value indicates that the IPOs outperform (underperform) the market in the selected period.

A simple t-test is used to test the null hypothesis of zero mean marketadjusted CAR:

$$
t=\frac{B H A R_{t} * \sqrt{n_{t}}}{\sigma\left(B H A R_{i, T}\right)}
$$




\section{REGRESSION RESULT}

Out of 112 samples of IPO companies during 1996 to 2001 period that the author uses, only 86 are used in the final sample whereas the remaining 26 IPO companies did not meet the data requirements. List of the final sample of IPO companies are shown below:

Table 1. Final IPO Samples 1996-2001

\begin{tabular}{|l|c|c|c|c|c|c|c|}
\hline \multicolumn{7}{|c|}{ IPO Companies and Industry Groups in 1996-2001 Periods } \\
\hline \multicolumn{1}{|c|}{ Industry Groups } & 1996 & 1997 & 1998 & 1999 & 2000 & 2001 & Total \\
\hline Agriculture & 1 & 1 & 0 & 2 & 1 & 0 & 5 \\
\hline Mining & 1 & 3 & 0 & 0 & 0 & 1 & 5 \\
\hline Basic Industry and Chemicals & 3 & 5 & 0 & 0 & 2 & 2 & 12 \\
\hline Miscellaneous Industry & 1 & 2 & 2 & 0 & 1 & 2 & 8 \\
\hline Consumer Goods Industry & 3 & 1 & 0 & 0 & 0 & 2 & 6 \\
\hline Property, Real Estate \& Building Construction & 1 & 4 & 1 & 1 & 3 & 3 & 13 \\
\hline Infrastructure, Utilities \& Transportation & 0 & 2 & 0 & 0 & 0 & 2 & 4 \\
\hline Finance & 1 & 6 & 1 & 1 & 4 & 5 & 18 \\
\hline Trade, Services \& Investment & 1 & 1 & 1 & 0 & 2 & 10 & 15 \\
\hline Total & 12 & 25 & 5 & 4 & 13 & 27 & 86 \\
\hline
\end{tabular}

The final sample shows that Indonesian companies going public in 19962001 are not evenly distributed across all 9 industries. These IPOs are mostly concentrated in four industry groups, which are Finance, Trade, Services \& Investment, Property, Real Estate \& Building Construction, and Basic Industry \& Chemicals. Furthermore, the highest number of IPOs occurred in 2001 and the lowest number of IPOs occurred in 1999. 


\section{Descriptive Statistics}

Table 2. Descriptive Statistics - Variables

\begin{tabular}{|lccccc|}
\hline & N & Mean & Min. & Max. & Std Deviation \\
\hline Initial Return (\%) & 86 & 42.32 & -30 & 270.83 & 60.36 \\
Age (Years) & 86 & 16 & 2 & 96 & 15.69 \\
Gross Proceeds (in billion IDR) & 86 & 100.85 & 7.8 & 927.36 & 168.35 \\
Annual Sales 3 years (in billion IDR) & 86 & $1,587.72$ & 3.69 & $41,222.47$ & $5,069.65$ \\
Annual Sales 5 years (in billion IDR) & 86 & $2,921.70$ & 5.57 & $68,064.53$ & $8,755.28$ \\
\hline
\end{tabular}

Initial return (IR) measures the return gained by investors from the difference between the price of stock at the close of first day with the offering price. The minimum and maximum IR of the samples are $-30 \%$ and $270.83 \%$ respectively with an average of $42.32 \%$ and standard deviation of $60.36 \%$.

Some companies prefer to go public fast while others go public in a really mature age. The youngest company is PT. Central Korporindo International Tbk with age of 2 and the oldest is PT. Bank Negara Indonesia Tbk with age of 96. On average, it takes the companies 16 years before they decided to go public and a standard deviation of 15.69 .

Gross proceeds measure the amount of earnings the companies received from selling stocks in IPOs. There is a significant difference in the amount, with smallest of 7.8 billion IDR from PT. Betonjaya Manunggal Tbk and largest of 927.36 billion IDR from PT. Bank Central Asia Tbk. Gross proceeds have an average of 100.85 billion IDR and standard deviation of 168.35.

Finally, based on annual sales, there is also a significant difference between the lowest and highest annual sales for three years and five years from the sample companies. For the three year period, the lowest annual sale is 3.69 billion IDR and the highest is $41,222.47$ billion IDR. On average, the three year annual sales of IPO companies is 1,587.72 billion IDR with a standard deviation of 5069.65 billion IDR. For the five year annual sales, the lowest annual sale is 5.57 billion IDR and the highest is $68,064.53$ billion IDR. On average, the annual sales of IPO companies is 2,921.70 billion IDR with a standard deviation of 8,755.28 billion IDR. 


\section{Results on Long-Run Performance}

Table 3. Long-Run Performance of IPOs

\begin{tabular}{|cccccc|}
\hline & Year 1 & Year 2 & Year 3 & Year 4 & Year 5 \\
\hline CAR (\%) & -9.24 & 12.30 & $\mathbf{1 5 . 8 3}$ & 23.61 & $\mathbf{- 1 . 0 0}$ \\
$\boldsymbol{t}$-stat & -1.067 & 0.668 & 0.842 & 0.953 & -0.040 \\
\hline BHAR (\%) & -19.75 & -45.49 & $\mathbf{- 6 8 . 0 2}$ & -94.31 & $\mathbf{- 1 3 9 . 7 0}$ \\
$\boldsymbol{t}$-stat & $-3.724^{* * *}$ & $-7.537^{* * *}$ & $-8.946^{* * *}$ & $-9.067^{* * *}$ & $-10.372^{* * *}$ \\
\hline
\end{tabular}

* significant at $10 \%, * *$ significant at $5 \%, * * *$ significant at $1 \%$

Table 4 reports long-run performance results of Indonesian IPOs. From the CAR results, the Indonesian IPOs show no results in outperforming the market. Since the results of three year CAR ( $t$-stat $=0.842$ ) and five year CAR ( $t$-stat $=-0.040$ ) are not significant, their performance is concluded to be similar with the market or follows the performance of the market.

On the contrary, calculations of abnormal returns using BHAR method report significant underperformances from the market. The three year buyand-hold return significantly underperforms the market by $-68.02 \%$ ( $t$ stat=-8.946 significant at $1 \%$ ) and the five year buy-and-hold return significantly underperforms the market by $-139.70 \%$ ( $t$-stat $=-10.372$ significant at $1 \%)$.

\section{Cross Sectional Analysis}

Tables 5 and 6 segment IPO companies based on its classification of business or its industry in the Indonesian Stock Exchange. Table 5 shows initial returns, CAR, and BHAR results and Table 6 shows the mean gross proceeds, annual sales, and age.

Result from the initial returns show that IPOs in Indonesia tend to earn large average initial returns and are heavily overvalued in the Trade, Services, and Investment industry, Property, Real Estate, and Building Construction industry, as well as Infrastructure, Utilities, and Transportation industry. Industries which are heavily overvalued tend to show poor long-run performance. This may be due to overvaluation or fads caused by over-optimism from investors at the time of the offering. 
The presence of fads also supports the argument that although early abnormal returns are significantly positive, prices will decline substantially in the years after the initial offering (Aggarwal and Rivoli 1990).

Table 4. Long-Run Performance Categorized By Industry

\begin{tabular}{|c|c|c|c|c|c|}
\hline \multirow{2}{*}{ Industry Groups } & \multirow{2}{*}{ IR (\%) } & \multicolumn{2}{|c|}{ CAR (\%) } & \multicolumn{2}{|c|}{ BHAR (\%) } \\
\hline & & 3 years & 5 years & 3 years & 5 years \\
\hline \multirow{2}{*}{ Agricultural } & 12.40 & -34.90 & -59.72 & -52.36 & -97.94 \\
\hline & $3.714^{* *}$ & -0.938 & -1.128 & $-7.305^{* * *}$ & $-3.982 * *$ \\
\hline \multirow[t]{2}{*}{ Basic Industry and Chemicals } & 32.14 & 49.03 & 4.79 & -53.57 & -94.47 \\
\hline & $2.381^{* *}$ & 0.864 & 0.070 & $-5.799 * * *$ & $-4.560^{* * *}$ \\
\hline \multirow[t]{2}{*}{ Consumer Goods Industry } & 19.58 & -1.50 & -25.52 & -56.84 & -128.78 \\
\hline & 1.380 & -0.038 & -0.381 & -1.616 & $-2.046 *$ \\
\hline \multirow[t]{2}{*}{ Finance } & 27.96 & 6.90 & -9.98 & -42.03 & -114.36 \\
\hline & $2.772^{* *}$ & 0.286 & -0.367 & $-2.176^{* *}$ & $-5.209 * * *$ \\
\hline \multirow[t]{2}{*}{$\begin{array}{l}\text { Infrastructure, Utilities, and } \\
\text { Transportation }\end{array}$} & 63.77 & 19.30 & -16.62 & -59.40 & -154.23 \\
\hline & 1.880 & 0.873 & -0.256 & $-4.420 * *$ & -1.724 \\
\hline \multirow[t]{2}{*}{ Mining } & 35.74 & 289.29 & 226.80 & -88.32 & -136.14 \\
\hline & 1.751 & 1.347 & 1.033 & $-2.265^{*}$ & -1.846 \\
\hline \multirow[t]{2}{*}{ Miscellaneous Industry } & 10.00 & 52.37 & 20.94 & -33.78 & -89.03 \\
\hline & 0.766 & 1.557 & 0.373 & -1.007 & -1.548 \\
\hline \multirow[t]{2}{*}{$\begin{array}{l}\text { Property, Real Estate, and Building } \\
\text { Construction }\end{array}$} & 70.23 & -16.93 & -45.14 & -92.55 & -160.41 \\
\hline & $3.017^{* *}$ & -0.449 & -1.337 & $-7.564 * * *$ & $-5.534 * * *$ \\
\hline \multirow[t]{2}{*}{ Trade, Services, and Investment } & 76.28 & -59.36 & -10.68 & -113.01 & -230.99 \\
\hline & $3.869 * * *$ & -2.017 & -0.113 & $-6.034 * * *$ & $-6.411 * * *$ \\
\hline \multirow[t]{2}{*}{ Total } & 42.32 & 15.83 & -1.00 & -68.02 & -139.70 \\
\hline & $6.502^{* * *}$ & 0.842 & -0.040 & $-8.946^{* * *}$ & $-10.372 * * *$ \\
\hline
\end{tabular}

* significant at $10 \%$, ** significant at $5 \%$, ***significant at $1 \%$

The CAR results in Table 5 report several differences across industry groups. Industry groups that show significant outperformance compared to the market are the Basic Industry and Chemicals Industry, Mining Industry, and Miscellaneous Industry. CARs for the Mining Industry 
reveal a very significant outperformance from the market. This differs significantly from the average CAR of the whole sample and thus is able to drag the CAR of the whole sample to a $15.83 \%$ in the third year and is only $-1 \%$ in the fifth year.

Industry groups that indicate significant underperformance compared to the market are Agricultural Industry, Property, Real Estate, and Building Construction Industry, and Trade, Services and Investment Industry. As the positive CARs from the mining industry covers up the negative CARs in the other industries, the CARs of the whole sample, in turn, turns out to be outperformance in the third year and a little bit underperformance in the fifth year. However, because all the results are not significant, the author cannot accept the validity of these results and cannot conclude that Indonesian IPOs outperform the market in the long-run.

Table 5. Mean Gross Proceeds, Annual Sales, and Age Categorized by Industry

\begin{tabular}{|c|c|c|c|c|c|}
\hline \multirow[t]{2}{*}{ Industry } & \multirow{2}{*}{$\begin{array}{l}\text { Number } \\
\text { of IPOs }\end{array}$} & \multirow{2}{*}{$\begin{array}{c}\text { Gross } \\
\text { Proceeds } \\
\text { (billion IDR) }\end{array}$} & \multicolumn{2}{|c|}{$\begin{array}{c}\text { Annual Sales (billion } \\
\text { IDR) }\end{array}$} & \multirow{2}{*}{$\begin{array}{c}\text { Age of } \\
\text { issuing } \\
\text { firm }\end{array}$} \\
\hline & & & 3 years & 5 years & \\
\hline Agricultural & 5 & $\begin{array}{l}156.10 \\
3.16^{* *}\end{array}$ & $\begin{array}{l}1,301.72 \\
3.883 * *\end{array}$ & $\begin{array}{l}2,638.41 \\
3.622 * *\end{array}$ & $\begin{array}{l}19.40 \\
4.13^{* *}\end{array}$ \\
\hline $\begin{array}{l}\text { Basic Industry and } \\
\text { Chemicals }\end{array}$ & 12 & $\begin{array}{c}124.54 \\
2.323 * *\end{array}$ & $\begin{array}{l}1,019.33 \\
4.037 * * *\end{array}$ & $\begin{array}{l}1,930.34 \\
4.019 * * *\end{array}$ & $\begin{array}{c}11.08 \\
6.721^{* * *}\end{array}$ \\
\hline Consumer Goods Industry & 6 & $\begin{array}{c}48.69 \\
4.073^{* * *}\end{array}$ & $\begin{array}{c}1,083.06 \\
1.461 \\
\end{array}$ & $\begin{array}{c}2,020.58 \\
1.544\end{array}$ & $\begin{array}{c}20.67 \\
4.986^{* * *} \\
\end{array}$ \\
\hline Finance & 18 & $\begin{array}{l}169.89 \\
2.521^{* *}\end{array}$ & $\begin{array}{c}4,080.54 \\
1.629\end{array}$ & $\begin{array}{c}7,197.14 \\
1.674 \\
\end{array}$ & $\begin{array}{c}25.33 \\
3.795 * * * \\
\end{array}$ \\
\hline $\begin{array}{l}\text { Infrastructure, Utilities, } \\
\text { and Transportation }\end{array}$ & 4 & $\begin{array}{c}34.30 \\
4.266^{* *}\end{array}$ & $\begin{array}{c}568.10 \\
1.616\end{array}$ & $\begin{array}{c}1,168.16 \\
1.897\end{array}$ & $\begin{array}{c}10.25 \\
3.573^{* *}\end{array}$ \\
\hline Mining & 5 & $\begin{array}{c}181.38 \\
1.711 \\
\end{array}$ & $\begin{array}{c}722.79 \\
1.649 \\
\end{array}$ & $\begin{array}{c}1,505.43 \\
1.411\end{array}$ & $\begin{array}{c}15.20 \\
2.896 * *\end{array}$ \\
\hline Miscellaneous Industry & 8 & $\begin{array}{c}53.52 \\
3.564^{* * *} \\
\end{array}$ & $\begin{array}{l}1,449.82 \\
2.752 * * \\
\end{array}$ & $\begin{array}{l}2,743.76 \\
2.878^{* *} \\
\end{array}$ & $\begin{array}{c}11.13 \\
4.768^{* * *} \\
\end{array}$ \\
\hline $\begin{array}{l}\text { Property, Real Estate, and } \\
\text { Building Construction }\end{array}$ & 13 & $\begin{array}{c}63.08 \\
4.1^{* * *}\end{array}$ & $\begin{array}{l}282.45 \\
2.594 * *\end{array}$ & $\begin{array}{c}446.54 \\
2.780^{* *}\end{array}$ & $\begin{array}{c}11 \\
6.975^{* * *}\end{array}$ \\
\hline $\begin{array}{l}\text { Trade, Services, and } \\
\text { Investment }\end{array}$ & 15 & $\begin{array}{r}50.40 \\
2.92 * * \\
\end{array}$ & $\begin{array}{l}446.58 \\
2.038^{*}\end{array}$ & $\begin{array}{l}587.15 \\
2.140^{*}\end{array}$ & $\begin{array}{c}12 \\
4.22 * * * \\
\end{array}$ \\
\hline All Firms & 86 & $\begin{array}{r}100.85 \\
5.555^{* * * *} \\
\end{array}$ & $\begin{array}{l}1,587.72 \\
2.904 * * * \\
\end{array}$ & $\begin{array}{l}2,921.70 \\
3.095^{* * *} \\
\end{array}$ & $\begin{array}{c}16 \\
9.199^{* * *} \\
\end{array}$ \\
\hline
\end{tabular}

* significant at $10 \%$, ** significant at 5\%, ***significant at $1 \%$ 
On the other hand, BHAR results in Table 5 shows the opposite of the CAR results where all the industry groups significantly underperform the market. The largest negative BHAR and the most significant underperformance are seen from the Trade, Services, and Investment Industry with three years BHAR of $-113.01 \%$ five years BHAR of 230.99\%. This fact supports the arguments stated by Aggarwal and Rivoli (1990) that stocks with high abnormal returns at the initial offering will experience underperformance in the long-run.

Table 6 is a cross-sectional analysis of industry groups based on mean gross proceeds, annual sales, and age of the whole sample. As seen from the table, gross proceeds in the mining, finance, agricultural, and basic industry and chemicals industries all exceed the mean gross proceeds of the whole sample. From annual sales, finance industry holds the highest position, followed by miscellaneous industry with property industry holding the lowest position. Furthermore, it can be seen that age has a strong relation with gross proceeds. This implies that more mature companies or the large size companies will sell stocks in an IPO with much more volume than younger companies.

\section{Results of Multiple Regressions}

The regression models for this research are:

$\mathrm{CAR}_{\mathrm{n}}=b_{0}+b_{1} \mathrm{IR}_{\mathrm{i}}+b_{2} \mathrm{AGE}_{\mathrm{i}}+b_{3} \mathrm{GP}_{\mathrm{i}}+b_{4} \mathrm{SALES}_{\mathrm{i}}+e_{i}$

BHAR $_{\mathrm{n}}=b_{0}+b_{1} \mathrm{IR}_{\mathrm{i}}+b_{2} \mathrm{AGE}_{\mathrm{i}}+b_{3} \mathrm{GP}_{\mathrm{i}}+b_{4} \mathrm{SALES}_{\mathrm{i}}+e_{i}$

Where $I_{i}$ is the initial return of stocks, $A E_{i}$ is the age of stocks, $G_{i}$ is the gross proceeds of stocks, and SALES $\mathrm{i}_{\mathrm{i}}$ is the annual sales of stocks.

The cross-sectional analysis documented in Table 5 and Table 6 are not independent towards one another. Thus, to further explain these relationships and to prove the hypotheses created by the author, Table 5 reports the results of multiple regression using the three year and five year CAR and BHAR as the dependent variable and initial return, age, gross proceeds, and annual sales as the independent variables.

\section{Hypothesis Testing Results}

The condition to accept $\mathrm{H}_{1}-\mathrm{H}_{6}$ is that for $10 \%$ significance level, t-stat $>$ 1.6639 or t-stat $<-1.6639$; for $5 \%$ significance level, t-stat $>1.9897$ or tstat $<-1.9897$; for $1 \%$ significance level, t-stat $>2.6379$ or t-stat $<-$ 2.6369. For the first hypothesis $\left(\mathrm{H}_{1}\right)$, the data from CAR reveals 
insignificant outperformance in the third year and insignificant underperformance in the fifth year. Thus, since the results are all insignificant, the author concludes to reject $\mathrm{H}_{1}$ because using CAR, the long-run performance of IPOs in Indonesia is similar with the market and cannot outperform the market.

Table 6. Multiple Regression Results of Three Years and Five Years

\begin{tabular}{|c|c|c|c|c|c|c|c|}
\hline \multicolumn{8}{|c|}{ Independent Variables } \\
\hline $\begin{array}{c}\text { Dependent } \\
\text { Variable }\end{array}$ & Constant & $\begin{array}{l}\text { Initial } \\
\text { Return }\end{array}$ & Age & $\begin{array}{c}\text { Gross } \\
\text { Proceeds }\end{array}$ & $\begin{array}{c}\text { Annual } \\
\text { Sales }\end{array}$ & $\mathrm{R}^{2}$ & $\mathrm{R}^{2}$ Adjusted \\
\hline \multirow[t]{2}{*}{ CAR3 } & 0.2612 & -0.3799 & 0.0020 & 0.0000 & 0.0000 & 0.0207 & -0.0277 \\
\hline & 0.790 & -1.163 & 0.140 & 0.182 & -0.074 & & \\
\hline \multirow[t]{2}{*}{ CAR5 } & -0.1268 & 0.1005 & 0.0035 & 0.0000 & 0.0000 & 0.0013 & -0.0480 \\
\hline & -0.284 & 0.228 & 0.183 & 0.113 & -0.069 & & \\
\hline \multirow[t]{2}{*}{ BHAR3 } & -0.5760 & -0.4322 & -0.0006 & 0.0000 & 0.0000 & 0.2377 & 0.2001 \\
\hline & $\begin{array}{c}- \\
4.885^{* * *}\end{array}$ & $-3.709 * * *$ & -0.127 & 0.798 & 1.082 & & \\
\hline \multirow[t]{2}{*}{ BHAR5 } & -1.2684 & -0.8867 & 0.0077 & 0.0000 & 0.0000 & 0.2829 & 0.2475 \\
\hline & - & $-4.426 * * *$ & 0.878 & 1.043 & 0.087 & & \\
\hline
\end{tabular}

* significant at $10 \%, * *$ significant at $5 \%$, ${ }^{* * *}$ significant at $1 \%$. For this multiple regression, the critical t-value is \pm 1.6639 for the 10 percent significance level, \pm 1.9897 for the 5 percent significance level, and \pm 2.6379 for $1 \%$ significance level (Berenson, Levine, and Krehbiel 2002).

Based on the BHAR results, IPO companies in Indonesia significantly underperform the market in the third year and significantly underperform the market in the fifth year. Thus, from the results, the author accepts $\mathrm{H}_{2}$ and concludes that Indonesian IPOs significantly underperform the market in the long-run.

For initial returns, data in the table above reports that using three year CAR, initial returns show negative coefficient and five year CAR shows positive IR coefficient, however both of them are not significant. Using three year and five year BHAR, the coefficients of IR are both negative and significant (-0.4322 and -0.8867). This implies that in Indonesian IPOs, offerings with better initial return performance results in larger underperformance in the long-run. Furthermore, the t-stats of BHAR are 
significant at the 1 percent level and provide further support to accept $\mathrm{H}$. The author concludes that initial returns have a negative relationship with long-run performance of IPOs in Indonesia. This conclusion presents the fact that Indonesian IPOs are overvalued at the time of the offering and may be subject of investor over-optimism or fads.

In terms of age, three out of 4 variables show positive coefficients, implying that older IPO companies will perform better in the long-run. However, based on t-stats the results are not significant, providing insufficient evidence to accept $\mathrm{H}_{4}$. Thus, the author concludes that age does not have a relationship with long-run performance of Indonesian IPOs.

For both gross proceeds and annual sales, all of the coefficients are 0 indicating that there is no relationship between gross proceeds and annual sales both has no relationship whatsoever towards long-run performance of IPOs. Furthermore, based on t-stats the results are all insignificant. Therefore, the author rejects $\mathrm{H}_{5}$ and $\mathrm{H}_{6}$ and concludes that gross proceeds do not have a relationship with long-run performance of Indonesian IPOs and annual sales do not have a relationship with long-run performance of Indonesian IPOs.

\section{CONCLUSION AND RECOMMENDATION}

With regard to certain limitations in this study, conclusions are made to answer the following five research questions:

1. Do Indonesian IPOs underperform the market in the long-run?

Indonesian companies that conducted IPOs during the period 1996-2001 are found to be underperforming the market. There is no significant evidence from CAR that these companies outperforms the market three years after the offering but there is significant evidence from BHAR that these companies significantly underperforms the market three years and five years after the offering.

2. Is there a relationship between initial return and long-run returns of IPO stocks?

There is a negative relationship between initial returns and long-run returns of IPO stock in Indonesia. This implies that IPO companies that 
give high initial returns at the time of the offering will perform poorer in the long-run. Moreover, this result indicates that there may be the presence of underpricing in the issuance of Indonesian IPOs.

3. Is there a relationship between age of companies and their long-run performance?

There is insufficient and insignificant evidence to prove that there is a relationship between age of IPO companies with their long-run performance. Thus, it is concluded that there is no relationship between age and long-run performance.

4. Is there a relationship between gross proceeds of IPO companies and their long-run performance?

There is insufficient and insignificant evidence to defend that there is a relationship between gross proceeds of IPO companies and their long-run performance. This implies that the earnings IPO companies get from selling the IPO stocks do not affect their performance in the long-run.

5. Is there a relationship between annual sales of IPO companies and their long-run performance?

There is insufficient and insignificant evidence to prove that there is a relationship between annual sales of IPO companies and their long-run performance. Thus, this implies that sales performance of IPO companies do not affect their long-run performance.

There are some limitations of this paper:

- There are limited studies regarding Indonesian IPOs. Thus, the author can only compare this research with a few researchers and there is only one study that is similar to what the author has done.

- There are difficulties in obtaining information, such as the historical stock prices of companies and the annual reports of the Indonesian IPO companies. Due to the lack of information provided by the Indonesian Stock Exchange, some companies are then excluded from the sample.

- Investors must be wise when deciding to invest in stocks of Indonesian public companies. As seen from the result of this research, the performance of Indonesian IPOs in the long-run is poor and there is no sufficient evidence that these IPOs outperform the market in the 
long-run. However, since the CAR and BHAR methods produced two different outcomes, investors must take this as a guide. The CAR method measures return of IPO stocks based on month to month basis whereas the BHAR method measures return using buy-and-hold basis. Thus, it will better for investors to trade Indonesian stocks monthly or regularly rather than just buy and hold it for several years. This will surely bring better returns for the investors.

- IPO companies in Indonesia must be careful when deciding their offering price at the time of the offering. Overvalued stocks are proven to have poor long-run performance. Thus, IPO companies must ensure that their underwriters choose the offering price carefully as it can affect the company's performance in the long-run.

\section{REFERENCES}

Aggarwal, R., \& Rivoli, P. (1990). Fads in the Initial Public Offering Market? The Journal of Financial Management, 45-57.

Barber, B. M., \& Lyon, J. D. (1997). Detecting long-run abnormal stock returns: the empirical power and specification of test statistics. Journal of Financial Economics, 43, 341-372.

Berenson, M. L., Levine, D. M., \& Krehbiel, T. C. (2002). Basic Business Statistics $\left(9^{\text {th }}\right.$ ed.). Upper Saddle River, NJ: Perason Education, Inc.

Berk, J., \& DeMarzo, P. (2007). Corporate Finance. USA: Pearson Education, Inc.

Bessler, W., \& Thies, S. (2007). The long-run performance of initial public offerings in Germany. Journal of Managerial Finance, 33(6), 420-441.

Brau, J. C., \& Fawcett, S. E. (2006). Initial Public Offerings: An Analysis of Theory and Practice. The Journal of Finance, 61(1), 399-436. 
Chi, J., McWha, M., \& Young, M. (2008). The Performance and Survivorship of New Zealand IPOs. Asian FA-NFA 2008 International Conference, Yokohama.

Chorruk, J., \& Worthington, A. (2009). The Pricing and Performance of IPOs for Small-and-Medium-Sized Enterprises: Emerging Market Evidence. Unpublished thesis, Griffith University, Nathan, Queensland.

Ellis, K., Michaely, R., \& O’Hara, M. (1999). A Guide to the Initial Public Offering Process. Unpublished thesis, Cornell University, Ithaca, New York.

Foerster, S. (2000). IPOs: The short and long of what we know. Canadian Investment Review, 45.

Geddes, R. (2003). IPOs \& Equity Offerings. Great Britain: ButterworthHeinemann.

Goergen, M., Khurshed, A., \& Mudambi, R. (2007). The long-run performance of UK IPOs: can it be predicted?. The Journal of Managerial Finance, 33(6), 401-419.

Kim, W., \& Weisbach, M. S. (2005). Do Firms Go Public To Raise Capital?. National Bureau of Economic Research, Working Paper 11197.

Kooli, M., \& Suret, J. (2001). The Aftermarket Performance of Initial Public Offerings in Canada. International Conference in Finance, Canada.

Loughran, T., Ritter, J. R. (1995). The New Issues Puzzle. The Journal of Finance, 50(1), 23-51.

Maksimovic, V., \& Pichler, P. (2001). Technological innovation and initial public offerings. Review of Financial Studies, 14, 459-494. 
Martani, D., (2004). Pengaruh Manajemen Informasi dan Determinan Lain Terhadap Harga Saham, Initial Return, dan Kinerja Saham Jangka Panjang: Studi Empiris Perusahaan Go Public di BEJ. Unpublished doctoral dissertation, University of Indonesia, Jakarta, Indonesia.

Miller, E. M. (1977). Risk, uncertainty, and divergence of opinion. The Journal of Finance, 32, 1151-1168.

Pagano, M., Panetta, F., \& Zingales, L. (1998). Why Do Companies Go Public? An Empirical Analysis. The Journal of Finance, 53(1), 2764.

Peng, L. (2008). Empirical Study on the Performance of Initial Public Offerings in China. Journal of Service, Science, \& Management, 2008(1), 135-142.

Pujiharjanto. (2003). Underpricing Pada Penawaran Umum Perdana di Bursa Efek Jakarta: Studi Empiris Emiten yang Listing Periode 1992-1998. Unpublished doctoral dissertation, University of Padjadjaran, Indonesia.

Purnanandam, A. K., \& Swaminathan, B. (2004). Are IPOs Really Underpriced?. The Review of Financial Studies, 17(3), 811-848.

Ritter, J. R. (1991). The Long-Run Performance of Initial Public Offerings. The Journal of Finance, 46(1), 3-27.

Ritter, J. R., \& Welch, I. (2002). A Review of IPO Activity, Pricing, and Allocations. Yale ICF Working Paper No. 02-01.

Rosul. M. (2002). The Capital Market in Indonesia's Economy: Development and Prospects. AT10 Research Conference.

Sohail, M. K., Nasr, M. (2007). Performance of Initial Public Offerings in Pakistan. International Review of Business Research Papers, 3(2), 420-441. 
Suherman. (2009). The Long-Run Performance of Indonesian Initial Public Offerings (IPOs). Unpublished thesis, State University of Jakarta, Jakarta, Indonesia.

Suroso. (2005). Hubungan Kinerja Jangka Panjang Saham Pasca-IPO dengan Optimisme dan Divergensi Opini Investor serta Tindakan Oportunis Emiten. Unpublished doctoral dissertation, University of Indonesia, Jakarta, Indonesia.

Teoh, H., Welch, I., \& Wong, T. (1998). Earning management and the long-term market performance of initial public offerings. Journal of Finance, 53, 421-449.

Thomadakis, S., Nounis, C., \& Gounopoulos, D. (2009). Long Term Performance of Greek IPOs. European Financial Management Journal, Forthcoming. 